\title{
Charcoal Rot of Strawberries Caused by Macrophomina phaseolina $^{1}$
}

\author{
N. A. Peres, J. S. Baggio, and J. C. Mertely ${ }^{2}$
}

\section{Introduction}

Charcoal rot is caused by Macrophomina phaseolina and has become more prevalent in Florida strawberry fields since methyl bromide was phased out. This disease was first observed in December 2001, when collapsed and dying strawberry plants from a commercial field were submitted to our diagnostic clinic (Mertely et al. 2005). Since then, samples have been received in our diagnostic clinic every season. During the 2015-2016 season, 30\% plant mortality due to charcoal rot was reported early in the season and reached more than $60 \%$ by the end of the season in some fields (Figure 1).

\section{Causal Agent and Symptoms}

Macrophomina phaseolina is distributed worldwide and has a host range of more than 500 plant species. The fungus produces resistant long-lived structures called sclerotia that survive in the soil and on strawberry debris. These microsclerotia are usually the primary source of new infections. Their numbers increase in the soil when susceptible hosts are grown continuously for several seasons.

Symptoms caused by Macrophomina phaseolina are similar to those caused by other crown-rot pathogens, such as Colletotrichum and Phytophthora species. Plants initially show signs of water stress and eventually collapse (Figure 2). Cutting the crowns of affected plants reveals reddish-brown necrotic areas along the margins and in the woody vascular ring (Figure 3 ). To confirm charcoal rot, a sample should be submitted to a diagnostic clinic, and the pathogen must be isolated from the diseased crowns and identified.

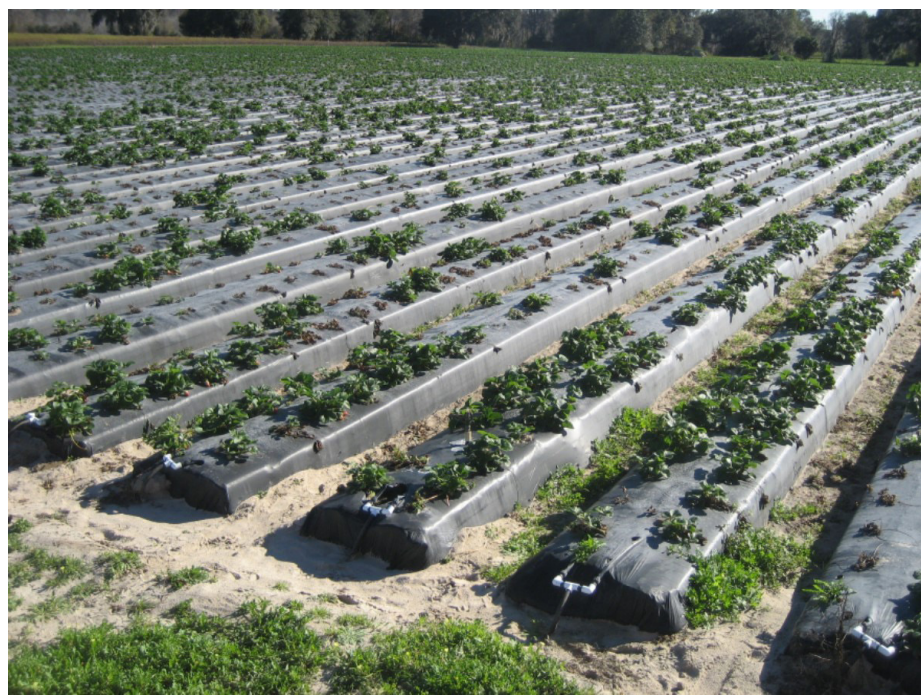

Figure 1. Strawberry field affected by charcoal rot during the 20152016 season.

Credits: Al Herndon

1. This document is PP242, one of a series of the Plant Pathology Department, UF/IFAS Extension. Original publication date October 2007. Revised February 2018. Visit the EDIS website at http://edis.ifas.ufl.edu.

2. N. A. Peres, professor; J. S. Baggio, postdoctoral associate; and J. C. Mertely, biological scientist IV; UF/IFAS Gulf Coast Research and Education Center, Wimauma, FL 33598.

The use of trade names in this publication is solely for the purpose of providing specific information. UF/IFAS does not guarantee or warranty the products named, and references to them in this publication does not signify our approval to the exclusion of other products of suitable composition. All chemicals should be used in accordance with directions on the manufacturer's label.

The Institute of Food and Agricultural Sciences (IFAS) is an Equal Opportunity Institution authorized to provide research, educational information and other services only to individuals and institutions that function with non-discrimination with respect to race, creed, color, religion, age, disability, sex, sexual orientation, marital status, national origin, political opinions or affiliations. For more information on obtaining other UF/IFAS Extension publications, contact your county's UF/IFAS Extension office. 


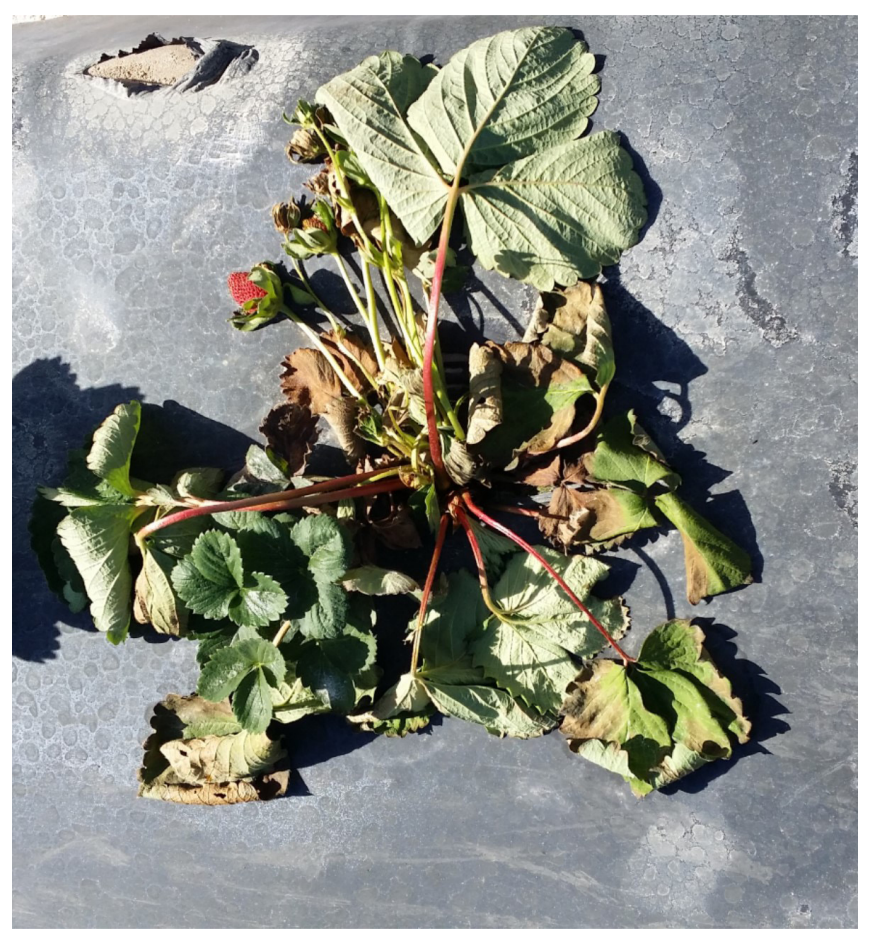

Figure 2. Strawberry plant wilting and collapsing due to charcoal rot. Credits: UF/IFAS

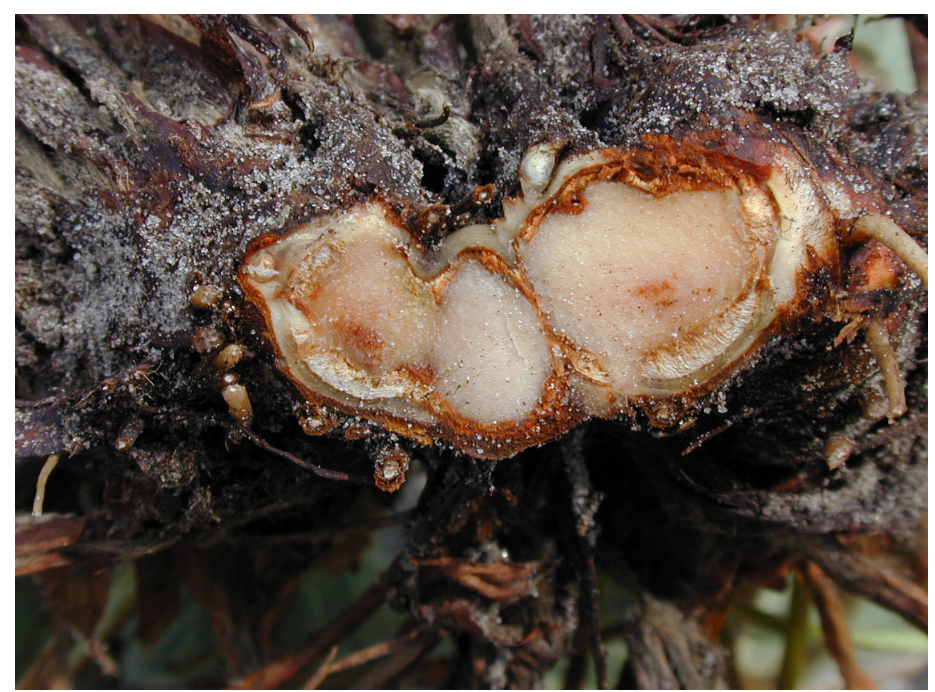

Figure 3. Internal symptoms of charcoal rot, including reddish-brown necrotic areas on the margins and woody vascular ring of the crown. Credits: UF/IFAS

\section{Disease Development and Spread}

M. phaseolina is a common soilborne pathogen in many warm areas of the world. Many vegetable crops planted as second crops after strawberry, such as squash, cantaloupe, peppers, and legumes used as cover crops, are susceptible to the pathogen. However, our research indicates that the strains that affect strawberries do not affect other crops and vice-versa. In general, high temperatures $\left(30^{\circ} \mathrm{C}\left[86^{\circ}\right.\right.$ F]), sandy soils, and low soil moisture favor infection and disease development. Soil is usually the primary source of inoculum, but there is evidence that the fungus can survive on crop residue, especially strawberry crowns that are incorporated into the soil or thrown between beds when the plastic is reused the following season. Additional research is still needed to confirm these observations and to investigate other factors that influence pathogen infection and disease development.

\section{Control}

Management of $M$. phaseolina involves a combination of cultural practices and chemical methods. Cultivars differ in their susceptibility to charcoal rot: 'Strawberry Festival' is highly susceptible, 'Florida Radiance' is moderately susceptible, and Sweet Sensation 'Florida 127' is moderately resistant. New cultivars developed by the University of Florida breeding program are tested for their susceptibility to $M$. phaseolina every season. Pre-plant soil fumigation is the standard method employed by growers to reduce inoculum levels and control charcoal rot. Methyl bromide was highly effective in controlling the pathogen. Since its phase-out, strawberry growers have transitioned to alternative broad-spectrum fumigants. Studies performed at the UF/IFAS Gulf Coast Research and Education Center (GCREC) in Balm, FL, at the Florida Strawberry Growers Association in Dover, and on commercial farms demonstrated that Telone ${ }^{\oplus}$, K-pam ${ }^{\oplus}$, Vapam ${ }^{\oplus}$, Paladin ${ }^{\oplus}$, and Dominus ${ }^{\oplus}$ applied through shank or drip tapes were effective in reducing inoculum of $M$. phaseolina placed at the center of the beds, but PicClor60 was not (Chamorro et al. 2016). However, these products may not effectively reduce inoculum placed on the sides of the beds due to their limited movement through the soil. The type of plastic used (VIF, TIF or LDPE) may also influence the efficacy of the fumigant used and, therefore, the control of the inoculum. In studies performed in Dover, Telone ${ }^{\circledast}$ applied under VIF plastic showed better results than when applied under LDPE plastic. Further studies with different fumigants, formulations, and methods of applications are still needed to attain better distribution of fumigants in the soil bed profile and more effective disease management.

Plant losses to charcoal rot can be reduced by chemigation or application of fungicides through the drip system. In chemigation experiments at UF/IFAS GCREC, Kenja, Rhyme $^{\mathrm{Tw}}$, Topsin, and Velum Prime suppressed charcoal rot when drip applied. Of these, RhymeTM and Velum Prime are currently labeled for drip application to strawberry, and only Rhyme has a specific label for charcoal rot. Several important points related to chemigation should be considered: 1) multiple drip applications may not perform as well as a properly applied pre-plant soil fumigation; 2) drip applications should outperform spray applications because $M$. phaseolina is a soil-borne pathogen; 3) applications made 
in the fall (when soil temperatures are high and plants are most susceptible) are the most effective; and 4) double drip tapes should perform better than single tapes when used as the conduit for fungicides or fumigants. Chemigation trials at UF/IFAS GCREC are continuing the search for more effective products and the development of proper labeling.

\section{Literature Cited}

Chamorro, M., T. E. Seijo, J. C. Noling, B. De los Santos, and N. A. Peres. 2016. "Efficacy of fumigant treatments and inoculum placement on control of Macrophomina phaseolina in strawberry beds." Crop Protection 90:163-169.

Mertely, J. C., T. Seijo, and N. A. Peres. 2005. "First report of Macrophomina phaseolina causing a crown rot of strawberry in Florida." Plant Disease 84:434. 
Table 1. Fungicides labeled in Florida for management of charcoal rot caused by Macrophomina phaseolina.

\begin{tabular}{|c|c|c|c|c|c|}
\hline \multirow{2}{*}{$\begin{array}{c}\text { Product name } \\
\text { (active ingredient) }\end{array}$} & \multirow{2}{*}{$\begin{array}{l}\text { Fungicide } \\
\text { Group }^{\mathrm{a}}\end{array}$} & \multicolumn{2}{|c|}{ Maximum Rate Per Acre } & \multirow{2}{*}{$\begin{array}{l}\text { Min. Days } \\
\text { to Harvest }\end{array}$} & \multirow[t]{2}{*}{ Remarks } \\
\hline & & Per Application & Per Season & & \\
\hline Rhyme (flutriafol) & 3 & $7 \mathrm{floz}$ & $28 \mathrm{fl} \mathrm{oz}$ & 0 & $\begin{array}{l}\text { Apply through drip irrigation. } \\
\text { Recommended initial application } \\
\text { at transplanting. For spring and fall } \\
\text { planting, a second application is required } \\
\text { approximately } 30 \text { days later. For fall } \\
\text { planting, additional applications may be } \\
\text { required at 30-day intervals. }\end{array}$ \\
\hline
\end{tabular}

a Fungicide group (FRAC Code): Numbers (1-37) and letters (M) are used to distinguish the fungicide mode of action groups. All fungicides within the same group (with the same numbers or letter) indicate same active ingredient or similar mode of action. This information must be considered for the fungicide resistance management decisions $\mathrm{M}=$ Multi-site inhibitors, fungicide resistance risk low. Source: FRAC Code List 2017; http://www.frac.info/ (FRAC = Fungicide Resistance Action Committee). n.a.: not applicable 